\title{
Contribution to the knowledge of the fauna of the long-tongued bees (Hymenoptera, Apoidea: Megachilidae, Apidae) in the north of the Arkhangelsk Region
}

\author{
GS Potapov ${ }^{1}$, YuS Kolosova ${ }^{1}$ \\ 1 N. Laverov Federal Center for Integrated Arctic Research, Russian Academy of Sciences (Arkhangelsk, Russian Federation) \\ Corresponding author: Grigory Potapov (grigorij-potapov@yandex.ru)
}

Academic editor: Yuliya V. Bespalaya • Received 5September 2019 • Accepted 9 October 2019 • Published 15 November 2019

Citation: Potapov GS, Kolosova YuS (2019) Contribution to the knowledge of the fauna of the long-tongued bees (Hymenoptera, Apoidea: Megachilidae, Apidae) in the north of the Arkhangelsk Region. Arctic Environmental Research 19(3): 99-105. https://doi. org/10.3897/issn2541-8416.2019.19.3.99

\begin{abstract}
This article is devoted to a study of the fauna of the long-tongued bees in the north of the Arkhangelsk Region, which is located in the northeast of the European part of Russia, but excludes the Arctic islands. This group includes the bees of the families Megachilidae and Apidae. Forty-four (44) species of bees were found in this region. Most of them (29) are bumblebees (genus Bombus). Fourteen (14) species are megachilid bees (genus Osmia, Coelioxys and Megachile) and one species is Apis mellifera. The largest number of species (39) was recorded in the lower reaches of the Northern Dvina River, due to the long research on this territory. The lowest number of species (16) was recorded in the Mezensky District. In the north of the studied region, the tundra species of $B$. lapponicus is only presented for the Mezensky District. Many species of bumblebees in the regional fauna belong to the ecological group of the meadow species. These are B. soroeensis, B. ruderarius, $B$. rupestris and a number of others. They are typical for meadow and ruderal habitats, and are usually not presented in the native taiga habitats. These meadow species are widely represented in the valleys of large rivers, such as the Northern Dvina, the Onega, and the Mezen. Compared to bumblebees, megachilid bees are much rarer in the north of the Arkhangelsk Region. Apis mellifera is presented in the lower reaches of the Northern Dvina River, but here it is rare, compared to the southern part of the Arkhangelsk Region.
\end{abstract}

\section{Keywords}

Osmia, Coelioxys, Megachile, Bombus, Apis, biodiversity, European North of Russia

Copyright Potapov GS, Kolosova YUS. This is an open access article distributed under the terms of the Creative Commons Attribution License (CC.BY 4.0), which permits unrestricted use, distribution, and reproduction in any medium, provided the original author and source are credited. 


\section{Introduction}

It is commonly known that according to the structure of the mouthparts, bees are divided into short-tongued and long-tongued (Michener 2007). The last group is considered as monophyletic and includes the families Megachilidae and Apidae (Danforth et al. 2006). The long-tongued bees (especially the honey bee and the bumblebees) have an important role as pollinators of many entomophilous plants (Proshchalykin 2009).

Despite the long history of studying bees in Russia, a number of regions are still poorly studied. These include the European North of Russia. Only bumblebees are investigated in detail for this region (main publications: Bolotov and Kolosova 2006, Bolotov et al. 2013, Potapov et al. 2014, Filippov 2014, Potapov and Kolosova 2016). Currently, there are a few published sources concerning megachilid bees (Sedykh 1974, Söderman and Leinonen 2003, Humala 2006, Polevoi et al. 2009, Kulakova 2011, Humala and Polevoi 2011, Annotated catalogue 2017). However, detailed information on the fauna of bees is known for the territory of Finland (Söderman and Leinonen 2003).

In this article, we present information on the fauna of long-tongued bees in the north of the Arkhangelsk Region.

\section{Materials and methods}

The northern part of the Arkhangelsk Region, except Novaya Zemlya and Franz Josef Land, is located mostly in the subzone of the northern taiga (Isachenko 1995). The southern part of the studied territory is a transition zone between middle taiga and northern taiga forests (Shmidt 2005). The transition between the northern taiga and forest tundra is found in the Mezensky District. The shrub tundra is located on the western coast of the Mezen Bay (Fedorov 1976). Various types of meadow and ruderal habitats are presented in the lower reaches of the large rivers, such as the Northern Dvina River (Shvartsman and Bolotov 2008, Parinova et al. 2014). They are typical sites for concentrations of bee individuals in the studied region.

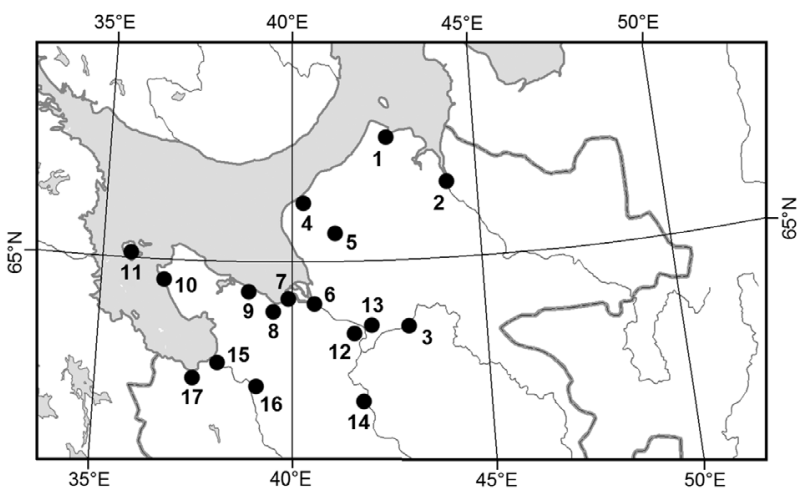

Fig. 1. Map of the northern part of the Arkhangelsk Region. Black circles indicate the collecting localities. Numbers for the collecting localities are given in Table 1

Table 1. The collecting localities of bees in the northern part of the Arkhangelsk Region

\begin{tabular}{llcc}
\hline № & \multicolumn{1}{c}{ Locality } & District & Coordinates \\
\hline 1 & Koyda & Mezensky & $66^{\circ} 22^{\prime} \mathrm{N}, 42^{\circ} 32^{\prime} \mathrm{E}$ \\
2 & Mezen & Pinezhsky & $65^{\circ} 49^{\prime} \mathrm{N}, 44^{\circ} 13^{\prime} \mathrm{E}$ \\
3 & Golubino & $64^{\circ} 33^{\prime} \mathrm{N}, 43^{\circ} 15^{\prime} \mathrm{E}$ \\
4 & Zimnyaya Zolotitsa & Primorsky & $65^{\circ} 41^{\prime} \mathrm{N}, 40^{\circ} 12^{\prime} \mathrm{E}$ \\
5 & Pomorye & & $65^{\circ} 19^{\prime} \mathrm{N}, 41^{\circ} 06^{\prime} \mathrm{E}$ \\
6 & Arkhangelsk & $64^{\circ} 32^{\prime} \mathrm{N}, 40^{\circ} 26^{\prime} \mathrm{E}$ \\
7 & Severodvinsk & $64^{\circ} 35^{\prime} \mathrm{N}, 39^{\circ} 48^{\prime} \mathrm{E}$ \\
8 & Solza River & $64^{\circ} 29^{\prime} \mathrm{N}, 39^{\circ} 32^{\prime} \mathrm{E}$ \\
9 & Syuzma & $64^{\circ} 42^{\prime} \mathrm{N}, 39^{\circ} 00^{\prime} \mathrm{E}$ \\
10 & Pushlakhta & $64^{\circ} 48^{\prime} \mathrm{N}, 36^{\circ} 34^{\prime} \mathrm{E}$ \\
11 & Solovetsky Islands & & $65^{\circ} 02^{\prime} \mathrm{N}, 35^{\circ} 70^{\prime} \mathrm{E}$ \\
12 & Kholmogory & & $64^{\circ} 14^{\prime} \mathrm{N}, 41^{\circ} 37^{\prime} \mathrm{E}$ \\
13 & Lukovetskiy & $64^{\circ} 30^{\prime} \mathrm{N}, 41^{\circ} 97^{\prime} \mathrm{E}$ \\
14 & Emetsk & & $63^{\circ} 27^{\prime} \mathrm{N}, 41^{\circ} 46^{\prime} \mathrm{E}$ \\
15 & Onega & & $63^{\circ} 54^{\prime} \mathrm{N}, 38^{\circ} 07^{\prime} \mathrm{E}$ \\
16 & Bolshoy Bor & $63^{\circ} 36^{\prime} \mathrm{N}, 39^{\circ} 06^{\prime} \mathrm{E}$ \\
17 & Maloshuyka & Onezhsky & $63^{\circ} 44^{\prime} \mathrm{N}, 37^{\circ} 24^{\prime} \mathrm{E}$ \\
\hline
\end{tabular}

The map of the north of the Arkhangelsk Region is given in Figure 1. The coordinates of the studied localities are given in Table 1. Most of bees in this study were collected during the period of 1994-2019 by the researchers from the Federal Center for Integrated Arctic Research of the Russian Academy of Sciences (FCIARctic) (PhD G.S. Potapov, PhD Yu.S. Kolosova, Dr.Sc. I.N. Bolotov, V.M. Spitsyn and PhD Yu.V. Bespalaya) and the Northern (Arctic) Federal University named after M.V. Lomonosov (NArFU) (PhD M.V. Podbolotskaya and Dr.Sc. B.Yu. Filippov). Additional material (bumblebees), concerning the period from 
the end of the nineteenth century to the first half of the twentieth century, was studied in the collections of the Zoological Institute of the Russian Academy of Sciences (Saint Petersburg, Russia).

The large part of the studied specimens from the north of the Arkhangelsk Region consists of bumblebees. These data are given in our previous articles (Bolotov et al. 2013, Potapov and Kolosova 2016, 2019). Additional unpublished materials (195 specimens) from the Onezhsky, Kholmogorsky and Primorsky Districts were collected in the period of 2017-2019. Apart from bumblebees, the studied material includes 50 specimens of Megachilidae and 35 specimens of Apis mellifera Linnaeus, 1758. The specimens of bees are deposited in the Russian Museum of the Biodiversity Hotspots (RMBH) of the FCIARctic, Arkhangelsk, Russia.

The species of the bees were identified according to Osychnyuk et al. (1978), Løken (1973, 1984), Söderman and Leinonen (2003), Rightmyer et al. (2010), Rasmont and Terzo (2017), and Falk and Lewington (2017). Identification of the bees was verified in the collection of the Finnish Museum of Natural History (Helsinki, Finland).

The general classification of the bees follows Michener (2007), particularly Gonzalez et al. (2012) for Megachilidae, and Williams (2018) for Bombini. The types of distributions of bees are given according the classification of Gorodkov (1984).

Notes concerning some species are:

1. We identified species of the Bombus lucorum complex solely on morphological characters. However, this method is not reliable in many cases and their identification requires using DNA barcoding (Bossert 2015). Both species, i.e., B. cryptarum (Fabricius, 1775) and B. lucorum (Linnaeus, 1761) are present in the European North (Pamilo et al. 1997, Potapov and Kolosova 2016).

2. Also, the distribution of $B$. modestus Eversmann, 1852 in the Arkhangelsk Region is questionable. This requires further clarification (Potapov and Kolosova 2016).

3. We include Megachile maackii Radoszkowski, 1874 in our species list. However, to our knowl- edge, at the present time the status of this species is in doubt (Annotated catalogue 2017). According to Praz (2017) this may be a subspecies of $M$. nigriventris Schenk, 1870.

The source of the map of the region is ESRI ArcGIS 10.0 software.

\section{Results}

According to the results of our study, 44 species of bees (Megachilidae and Apidae) are found in the north of the Arkhangelsk Region (Table 2). The greatest number of species is recorded in the Primorsky District (39 species), and the least number of species is in the Mezensky District (16 species). Among the found species, most (29) are bumblebees (genus Bombus). Fourteen (14) species are megachilid bees (genus Osmia, Coelioxys and Megachile) and one species is Apis mellifera.

Most of the species of the studied fauna are Transpalaearctic (28 species), 9 species are Holarctic, 4 speacies are Sub-Transpalaearctic, 2 species are West-Central Palaearctic and one species (A. mellifera) is Cosmopolitan.

\section{Discussion}

If we consider the obtained results, it can be concluded that the study of the bee fauna of the north of the Arkhangelsk Region is still far from complete. Only the fauna of bumblebees has been sufficiently studied for the studied territory (Potapov and Kolosova 2016). In contrast, only 14 megachilid bees were found in the north of the Arkhangelsk Region (Table 2). To our knowledge, these are the first published data for the studied territory.

The greatest number of the Megachilidae species (11) is recorded in the Primorsky District (Table 2). The reason for this is the large amount of research since the 1990s in the lower reaches of the Northern Dvina River. Only in the mid-2000s did studies begin in other districts of the Arkhangelsk Region. 
Table 2. List of the species of bees (Megachilidae and Apidae) that are recorded in the northern part of the Arkhangelsk Region.

\begin{tabular}{|c|c|c|c|c|c|c|c|}
\hline \multirow[t]{2}{*}{ № } & \multirow[t]{2}{*}{ Species } & \multirow[t]{2}{*}{ Type of distribution } & \multicolumn{5}{|c|}{ District of the Arkhangelsk Region } \\
\hline & & & $\mathrm{Mz}$ & Pn & $\operatorname{Pr}$ & Khl & On \\
\hline 1 & Osmia (Melanosmia) inermis (Zetterstedt, 1838) & Hol & - & - & $\cdot$ & - & - \\
\hline 2 & O. (M.) nigriventris (Zetterstedt, 1838) & Hol & - & • & - & - & - \\
\hline 3 & Coelioxys (Boreocoelioxys) inermis (Kirby, 1802) & $\mathrm{Tp}$ & - & - & - & - & - \\
\hline 4 & C. (Coelioxys) elongatus Lepeletier, 1841 & $\mathrm{Tp}$ & - & - & - & - & - \\
\hline 5 & Megachile (Megachile) alpicola Alfken, 1924 & $\mathrm{Tp}$ & - & - & • & - & - \\
\hline 6 & M. (M.) centuncularis (Linnaeus, 1758) & Hol & - & - & - & - & - \\
\hline 7 & M. (M.) lapponica Thomson, 1872 & Hol & - & • & - & - & - \\
\hline 8 & M. (M.) ligniseca (Kirby, 1802) & $\mathrm{Tp}$ & - & - & - & - & - \\
\hline 9 & M. (Xanthosarus) analis Nylander, 1852 & $\mathrm{Tp}$ & - & - & - & - & - \\
\hline 10 & M. (X.) circumcincta (Kirby, 1802) & Hol & - & - & - & - & - \\
\hline 11 & M. (X.) lagopoda (Linnaeus, 1761) & $\mathrm{Tp}$ & - & - & - & - & - \\
\hline 12 & M. (X.) cf. maackii Radoszkowski, 1874 & $\mathrm{Tp}$ & - & - & • & - & - \\
\hline 13 & M. (X.) nigriventris Schenk, 1870 & $\mathrm{Tp}$ & - & - & - & - & - \\
\hline 14 & M. (X.) willughbiella (Kirby, 1802) & $\mathrm{Tp}$ & - & - & • & - & • \\
\hline 15 & Bombus (Kallobombus) soroeensis (Fabricius, 1777) & $\mathrm{Tp}$ & • & - & - & • & - \\
\hline 16 & B. (Subterraneobombus) distinguendus Morawitz, 1869 & Hol & • & • & - & - & • \\
\hline 17 & B. $($ Megabombus $)$ hortorum (Linnaeus, 1761) & $\mathrm{Tp}$ & • & - & - & • & - \\
\hline 18 & B. (Mg.) consobrinus Dahlbom, 1832 & STp & - & • & - & - & - \\
\hline 19 & B. (Thoracobombus) muscorum (Linnaeus, 1758) & $\mathrm{Tp}$ & • & - & • & • & - \\
\hline 20 & B. (Th.) ruderarius (Müller, 1776) & $\mathrm{Tp}$ & - & • & - & • & • \\
\hline 21 & B. (Th.) veteranus (Fabricius, 1793) & $\mathrm{Tp}$ & • & • & - & - & - \\
\hline 22 & B. (Th.) humilis Illeger, 1806 & $\mathrm{Tp}$ & - & - & - & • & - \\
\hline 23 & B. (Th.) pascuorum (Scopoli, 1763) & $\mathrm{Tp}$ & • & • & - & • & - \\
\hline 24 & B. (Th.) schrencki Morawitz, 1881 & $\mathrm{STp}$ & - & • & - & • & • \\
\hline 25 & B. (Psithyrus) rupestris (Fabricius, 1793) & $\mathrm{Tp}$ & - & - & • & $\cdot$ & - \\
\hline 26 & B. (Ps.) bohemicus Seidl, 1837 & $\mathrm{Tp}$ & • & • & • & • & • \\
\hline 27 & B. (Ps.) barbutellus (Kirby, 1802) & $\mathrm{Tp}$ & - & • & - & • & - \\
\hline 28 & B. (Ps.) flavidus Eversmann, 1852 & Hol & • & - & • & • & • \\
\hline 29 & B. (Ps.) norvegicus (Sparre-Schneider, 1918) & $\mathrm{Tp}$ & - & • & - & • & - \\
\hline 30 & B. (Ps.) quadricolor (Lepeletier, 1832) & W-Cp & - & - & - & • & - \\
\hline 31 & B. (Ps.) sylvestris (Lepeletier, 1832) & $\mathrm{Tp}$ & - & • & - & • & - \\
\hline 32 & B. (Pyrobombus) lapponicus (Fabricius, 1793) & $\mathrm{Tp}$ & - & - & - & - & - \\
\hline 33 & B. (Pr.) hypnorum (Linnaeus, 1758) & $\mathrm{Tp}$ & • & • & - & • & - \\
\hline 34 & B. (Pr.) cf. modestus Eversmann, 1852 & $\mathrm{Tp}$ & - & • & - & - & - \\
\hline 35 & B. (Pr.) pratorum (Linnaeus, 1761$)$ & W-Cp & • & • & - & • & - \\
\hline 36 & B. (Pr.) jonellus (Kirby, 1802) & Hol & • & • & - & • & - \\
\hline 37 & B. (Pr.) cingulatus Wahlberg, 1854 & $\mathrm{Tp}$ & • & • & - & • & - \\
\hline 38 & B. (Bombus) sporadicus Nylander, 1848 & $\mathrm{Tp}$ & • & • & - & • & • \\
\hline 39 & B. (Bo.) cf. lucorum (Linnaeus, 1761) & $\mathrm{Tp}$ & - & - & - & • & - \\
\hline 40 & B. (Bo.) patagiatus Nylander, 1848 & STp & - & - & - & - & - \\
\hline 41 & B. (Bo.) cf. cryptarum (Fabricius, 1775) & Hol & • & • & • & • & • \\
\hline 42 & B. (Melanobombus) sichelii Radoszkowski, 1860 & $\mathrm{Tp}$ & • & • & • & - & • \\
\hline 43 & B. (Cullumanobombus) semenoviellus Skorikov, 1910 & $\mathrm{STp}$ & - & • & - & - & • \\
\hline 44 & Apis mellifera Linnaeus, 1758 & Cs & - & - & - & • & - \\
\hline \multicolumn{3}{|c|}{ Total number of species } & 16 & 25 & 39 & 28 & 26 \\
\hline
\end{tabular}

Notes: Type of distribution: Cs - Cosmopolitan, Hol - Holarctic, Tp - Transpalaearctic, W-Cp - West-Central-Palaearctic, STp - Sub-Transpalaearctic. District of the Arkhangelsk Region: Mz - Mezensky, Pn - Pinezhsky, Pr - Primorsky, Khl - Kholmogorsky, On - Onezhsky. Symbols: (•) - recorded, according to the examined material, $(-)$ - absent. 
No megachilid bees are found in the Mezensky District. Here, only bumblebees (16 species) are recorded. The northern part of the Arkhangelsk Region is the northern edge of the distribution of Megachilidae in the north-eastern European North of Russia. In Eastern Fennoscandia a number of species (for example, $O$. inermis, $O$. nigriventris) reach the northern part of the Murmansk Region and Norway (Söderman and Leinonen 2003). It is probable that these two species would be found in the Mezensky District following more detailed research over long time periods.

Compared to neighbouring regions, there is a lesser number of recorded species of the family Megachilidae in the north of the Arkhangelsk Region. Seventeen (17) species in the Komi Republic (Sedykh 1974) and 26 species in the middle part of Finland and Karelia (Söderman and Leinonen 2003) are known. Obviously, further studies would increase the number of recorded species of megachilid for the Arkhangelsk Region.

All of these recorded species of the family Megachilidae are also known from Finland and Karelia (Söderman and Leinonen 2003). A number of them have a decline in their abundance and are classified as near threatened or regionally extinct species, and these are M. centuncularis and M. lagopoda (Rassi et al. 2010, Hyvärinen et al. 2019). Other megachilid bees in Finland are either common or are also in decline in the second half of the twentieth century (Söderman and Leinonen 2003). Our data do not allow us to adequately assess the rarity of these species in the region. However, the obvious lower abundance of megachilid bees, compared to bumblebees, in the north of the Arkhangelsk Region requires continuous monitoring of their populations. A possible decline of bee populations under anthropogenic influences may have consequences such as the disappearance of some species from the regional fauna.

In this study, A. mellifera was found in the lower reaches of the Northern Dvina River (Primorsky and Kholmogorsky Districts), but here it is rare compared to the southern part of the Arkhangelsk Region.

Among the bumblebees, $B$. patagiatus is the rarest species in the north of the Arkhangelsk Region. Only one specimen of this species was collected near Severodvinsk in 2013 (Potapov and Kolosova 2019).
A number of bumblebee species have specificities in their distribution in the north of the Arkhangelsk Region. Only in the north of this region is the tundra species of B. lapponicus presented. It is recorded in the Mezensky District (Koyda and Mezen) (Potapov and Kolosova 2016). This species does not reach more southern localities in the north of the Arkhangelsk Region (Potapov and Kolosova 2016).

B. consobrinus, however, is presented quite locally in most districts of the studied region (Table 1). This species is considered as monolectic in Fennoscandia and is related with Aconitum septentrionale (Løken 1973, Pekkarinen and Teräs 1993, Söderman and Leinonen 2003). In the north of the Arkhangelsk Region, B. consobrinus is most abundant in the boreal ecosystems of the Pinezhsky District (Bolotov and Kolosova 2006) but it is rare in the other areas of the studied region (Potapov and Kolosova 2016). B. consobrinus is also rare in Finland and Karelia (Söderman and Leinonen 2003, Parkkinen et al. 2018).

As a separate group of species in the regional fauna, the bumblebee species can be distinguished, such as B. soroeensis, B. ruderarius, B. rupestris, and a number of others. They are typical for meadow and ruderal habitats, and they are usually not presented in the native taiga habitats (Potapor and Kolosova 2016, 2019). These meadow species are widely presented in the valleys of large rivers such as the Northern Dvina, the Onega, and the Mezen. These patterns are well known and they are studied in detail for the Arkhangelsk Region (Potapov and Kolosova 2016, 2017, 2019).

In the studied region, species of bees with wide ranges are present, which is typical for the European North of Russia (Potapov and Kolosova 2016). This is a result of the post-glacial origin of the regional bee fauna (Løken 1973, Pekkarinen and Teräs 1993, Shvartsman and Bolotov 2008).

\section{Conclusion}

The fauna of the long-tongued bees (Megachilidae and Apidae) of the north of the Arkhangelsk Region has 44 species and most of them are bumblebees. The re- 
gional fauna is typical for the European North of Russia. Future studies should be directed towards a more detailed study of local bee faunae. This will increase the number of observed megachilid species for different districts of the north of the Arkhangelsk Region.

\section{Acknowledgements}

We are especially grateful to PhD M.V. Podbolotskaya (1956-2014), who established bumblebee research in the Arkhangelsk Region. We are indebted to Dr. Sc. I.N. Bolotov, Dr. Sc. B.Yu. Filippov, PhD Yu.V. Bespalaya and V.M. Spitsyn who generously supplied us

\section{References}

- Annotated catalogue (2017) Annotated catalogue of the Hymenoptera of Russia. Volume I. Symphyta and Apocrita: Aculeata. In: Lelej AS, Proshchalykin MYu, Loktionov VM (Eds) Proceedings of the Zoological Institute RAS, Supplement 6, 475 pp.

- Bolotov IN, Kolosova YuS (2006) Trends in the formation of biotopic complexes of bumblebees (Hymenoptera, Apidae: Bombini) in the northern taiga karst landscapes of the Western Russian Plain. Russian Journal of Ecology 37 (3): 156-166. https://doi.org/10.1134/S1067413606030039

- Bolotov IN, Kolosova YuS, Podbolotskaya MV, Potapov GS, Grishchenko IV (2013) Mechanism of density compensation in island bumblebee assemblages (Hymenoptera, Apidae, Bombus) and the notion of reserve compensatory species. Biology Bulletin 40(3): 318-328. https://doi.org/10.1134/S1062359013030035

- Bossert S (2015) Recognition and identification of bumblebee species in the Bombus lucorum-complex (Hymenoptera, Apidae) - a review and outlook. Deutsche Entomologische Zeitschrift 62(1): 19-28. https://doi.org/10.3897/dez.62.9000

- Danforth BN, Sipes S, Fang J, Brady SG (2006) The history of early bee diversification based on five genes plus morphology. Proceedings of the National Academy of Sciences of the United States of America 103(41): 15118-15123. https://doi. org/10.1073/pnas.0604033103

- Falk S, Lewington R (2017) Field guide of the bees of Great Britain and Ireland. Bloomsbury, London, $432 \mathrm{pp}$.

- Fedorov VD (1976) Atlas of Arkhangelsk Region. The Main Department of Geodesy and Cartography of the Council of Ministers of the USSR, Moscow, $72 \mathrm{pp}$. with material from some localities of the Arkhangelsk Region. We would like to thank PhD Juho Paukkunen (Finnish Museum of Natural History, Helsinki) for assistance in studying bees and providing us with access to the collection of the Museum for the purposes of this research. Also, we are grateful to the staff of the Zoological Institute of Russian Academy of Sciences, Saint-Petersburg for the opportunity to examine collections. We thank PhD M.Yu. Gofarov, who supplied us with the map. This study was supported by the project of the Ministry of Education and Science of the Arkhangelsk Region "Young Scientists of Pomorye" (no. 14-2019-02a). Special thanks are due to Dr. M. Copley for improving the language of the article.

- Filippov NY (2014) Diversity and ecology of bumblebees (Hymenoptera, Apidae, Bombus Latr.) in the European NorthEast of Russia. PhD Thesis, Institute of Biology of Komi Scientific Centre of the Ural Branch of the RAS, Syktyvkar.

- Gonzalez VH, Griswold T, Praz CJ, Danforth BN (2012) Phylogeny of the bee family Megachilidae (Hymenoptera: Apoidea) based on adult morphology. Systematic Entomology 37(2): 261-286. https://doi.org/10.1111/j.13653113.2012.00620.x

- Gorodkov KB (1984) Types of areas of tundra and forests zones insects of the European Part of the USSR. Areas of insects in the European part of the USSR: Atlas, Maps 179-221. Nauka, Leningrad, 3-20.

- Humala AE (2006) On the insect fauna of Kivach Nature Reserve. Proceedings of the Karelian Scientific Centre of the RAS 10: 153-159.

- Humala AE, Polevoi AV (2011) Records of new and remarkable insect species (Insecta) in Northern Ladoga Area. Proceedings of the Karelian Scientific Centre of the RAS 2: 142-144.

- Isachenko AG (1995) Physical and geographical characteristics of the region. In: Frolov AK (Ed.) State of the environment of the North-Western and Northern regions of Russia. Nauka, Saint-Petersburg, 7-30.

- Kulakova OI (2011) Hymenoptera. In: Tatarinov AG (Ed.) Fauna of the Komi Republic. Arachnida and Insecta. Institute of Biology of Komi Scientific Centre of the Ural Branch of the RAS, Syktyvkar, 161-191. 
Løken A (1973) Studies of Scandinavian bumblebees (Hymenoptera, Apidae). Norsk Entomologisk Tidsskrift 20(1): 1-218.

- Løken A (1984) Scandinavian species of the genus Psithyrus Lepeletier (Hymenoptera, Apidae). Entomologica Scandinavica 23: 1-45.

- Michener CD (2007) The bees of the world. Second edition. The Johns Hopkins University Press, Baltimore, 953 pp.

- Osychnyuk AZ, Panfilov DV, Ponomareva AA (1978) Superfamily Apoidea. In: Skarlato OA (Ed.) Keys for the insects of the European part of the USSR. Volume III. Hymenoptera. Part I. Nauka, Leningrad, 279-519.

- Pamilo P, Tengö J, Rasmont P, Pirhonen K, Pekkarinen A, Kaarnama E (1997) Pheromonal and enzyme genetic characteristics of the Bombus lucorum species complex in Northern Europe. Entomologica Fennica 7: 187-194. https:/doi. org/10.33338/ef.83908

- Parinova TA, Nakvasina EN, Sidorova OV (2014) Meadows of the island floodplain in the delta of the North Dvina River. Northern (Arctic) Federal University, Arkhangelsk, 146 pp.

- Parkkinen S, Paukkunen J, Teräs I (2018) Suomen kimalaiset. Docendo Oy, Yuväskylä, 176 pp.

- Pekkarinen A, Teräs I (1993) Zoogeography of Bombus and Psithyrus in Northwestern Europe (Hymenoptera, Apidae). Annales Zoologici Fennici 30(3): 187-208.

- Polevoi AV, Humala AE, Gorbach VV, Uzenbaev SD (2009) Changes and additions to the list of rare and vulnerable insect species of Republic of Karelia. Proceedings of the Karelian Scientific Centre of the RAS 1: 90-97.

- Potapov GS, Kolosova YuS, Gofarov MYu (2014) Zonal distribution of bumblebee species (Hymenoptera, Apidae) in the North of European Russia. Entomological Review 94(1): 79-85. https://doi.org/10.1134/S0013873814010096

- Potapov GS, Kolosova YuS (2016) Fauna of bumblebees (Hymenoptera: Apidae: Bombus Latr.) in the mainland part of Arkhangelsk Region, NW Russia. Annales de la Société entomologique de France (N.S.) 52(3): 150-160. https://doi.org/10. 1080/00379271.2016.1217167

- Potapov GS, Kolosova YuS (2017) Local faunae of bumblebees (Hymenoptera: Apidae, Bombus Latr.) in the European North of Russia: vicinity of the town of Shenkursk. Arctic En- vironmental Research 17(1): 41-49. https://doi.org/10.17238/ issn2541-8416.2017.17.1.41

- Potapov GS, Kolosova YuS (2019) Local fauna of bumblebees (Hymenoptera, Apidae) in the lower reaches of the Northern Dvina River. Arctic Environmental Research 19(2): 49-55. https://doi.org/10.3897/issn2541-8416.2019.19.2.49

- Praz CJ (2017) Subgeneric classification and biology of the leafcutter and dauber bees (genus Megachile Latreille) of the western Palearctic (Hymenoptera, Apoidea, Megachilidae). Journal of Hymenoptera Research 55: 1-54. https://doi. org/10.3897/jhr.55.11255

- Proshchalykin MYu (2009) The long-tongued bees (Hymenoptera, Apoidea: Megachilidae, Apidae) of Transbaikalia. Vestnik Kharkovskogo natsionalnogo universiteta imeni V.N. Karazina. Ser.: Biologia 9 (856): 136-142.

- Rasmont P, Terzo M (2017) Catalogue et clé des sous-genres et espèces du genre Bombus de Belgique et du nord de la France (Hymenoptera, Apoidea). 2e édition. Mons University, Mons, 28 pp.

- Rassi P, Hyvärinen E, Juslén A, Mannerkoski I (2010) Suomen lajien uhanalaisuus - Punainen kirja 2010. Ympäristöministeriö \& Suomen ympäristökeskus, Helsinki, 685 pp.

- Rightmyer MG, Griswold T, Arduser MS (2010) A review of the non-metallic Osmia (Melanosmia) found in North America, with additional notes on palearctic Melanosmia (Hymenoptera, Megachilidae). ZooKeys 60: 37-77. https://doi. org/10.3897/zookeys.60.484

- Sedykh KF (1974) Fauna of the Komi ASSR. Invertebrates. Komi knizhnoe izdatelstvo, Syktyvkar, 188 pp.

- Shvartsman YuG, Bolotov IN (2008) Spatio-temporal heterogeneity of the taiga biome in the Pleistocene continental glaciations. The Ural Branch of the RAS, Ekaterinburg, 302 pp.

- Söderman G, Leinonen R (2003) Suomen mesipistiäiset ja niiden uhanalaisuus. Tremex Press, Helsinki, 420 pp.

- Hyvärinen E, Juslén A, Kemppainen E, Uddström A, Liukko UM (2019) Suomen lajien uhanalaisuus - Punainen kirja 2019. Ympäristöministeriö \& Suomen ympäristökeskus, Helsinki, 704 pp.

- Williams PH (2018) Bumblebees of the World. The Natural History Museum, London. http://www.nhm.ac.uk/research-curation/projects/bombus/index.html 